\title{
TENDENCIJE U SUVREMENIM FASADAMA U RIJECI
}

\section{TRENDS IN CONTEMPORARY FACADES IN RIJEKA}

\author{
Iva Mrak*, Edin Redžović
}

\begin{abstract}
Sažetak
Kako je 19. stoljeće stoljeće razvoja konstrukcija, tako je 20. stoljeće je stoljeće razvoja novih materijala za konstrukcije, ali i završne radove pa tako razvoj i upotrebu konstrukcija uvedenih u 19. i 20. stoljeću slijedi i razvoj fasadnih sistema. U radu se analizira ovaj razvoj na primjerima u Rijeci i riječkoj okolici.
\end{abstract}

Ključne riječi: fasade, Rijeka, moderna arhitektura, suvremena arhitektura

\begin{abstract}
Since the $19^{\text {th }}$ century is the century of the development of structures, the $20^{\text {th }}$ century is the century of the development of new construction and finishing works materials. Thus, the development and use of the structures introduced in the $19^{\text {th }}$ and $20^{\text {th }}$ centuries is also followed by the development of the façade systems. The paper analyzes the development of the case studies in Rijeka and its surrounding area.
\end{abstract}

Key words: façades, Rijeka, modern architecture, contemporary architecture

* Građevinski fakultet Sveučilišta u Rijeci, Radmile Matejčić 3, 51000 Rijeka

E-mail: iva.mrak@gradri.uniri.hr; edin.redzovic@student.uniri.hr 


\section{Uvod}

Dok suvremene konstrukcije počinju svoj razvoj velikim dijelom u 19. stoljeću (posebno se radi o armiranom betonu i čeliku) [1, 2], u 20. stoljeću njihova se upotreba rasprostranjuje, ali i prati razvojem materijala i tehnologija završnih radova, kao što su fasade. Posebno je karakterističan primjer ovješenih fasadnih sistema (curtain-wall) koje su danas nezamjenjiv dio suvremenog okoliša [3]. Dok su tradicionalne fasade prvenstveno štitile zgradu od kiše (npr. tradicionalne žbuke) te osiguravale zgradama estetski dojam (fresco, kamene fasade...), danas su zahtjevi koje se traže od fasadnih sistema sve raznovrsniji, a uključuju toplinski i zvučnu izolaciju, vatrootpornost, zaštitu od buke, higijenu [4], jednostavnost i brzinu izvedbe, dugotrajnost pa čak i reakciju na okoliš (npr. proizvodnjom električne energije ili mijenjanjem svojstava), a različiti slojevi pridonose različitim funkcijama (sprečavanje prolaza vodene pare, ulaska kiše, stvaranja kondenzacije, toplinska izolacija...) [5].

Rijeka i riječka okolica su danas priznati kao područje gdje su moderni i suvremeni stilovi dosegli značajan razvoj (secesija, moderna, poslijeratna arhitektura...) u primjerima konstrukcija, što je dokumentirano i u brojnoj literaturi, npr. $[6,7,8,9,10]$. Cilj rada je shvatiti razvoj i upotrebu tehnologija suvremenih fasada na primjerima u gradu Rijeci i okolici te posebno odgovoriti na istraživačka pitanja (navedena u dijelu rada „Metodologije i materijali“) kako bi se dao uvid u razvoj fasada, posebno u suvremenom periodu (rad se prvenstveno bavi razvojem fasada od Drugog svjetskog rata do danas, dok je radi razumijevanja razvoja fasada $u$ vremenskom slijedu dan pregled i međuratne arhitekture kada se pojavljuju tendencije koje se kasnije razvijaju) te time pridonijeti stvaranju kulturne (kako definirano u [11] i tehničke (sfere ljudskog djelovanja koji su nerazdvojno povezane, npr. [12]) podloge za razumijevanje procesa razvoja fasada, utjecaja tehnologije i inovativnosti na kvalitetu fasade zgrade, čime bi se stvorila baza za dokumentiranje, prezentaciju, obnovu, ali i kreiranje novih fasada koje bi odražavale visoku razinu istraženih primjera na lokalnoj razini.

\section{Metodologije i materijali}

Već pri samom postavljanju teme nailazi se na različite termine kao što su „fasada“, „fasadni sistem“ i „ovojnica“. Fasada je definirana u [13] kao „1. arhit. a. prednja strana zgrade; pročelje b. gornji vanjski sloj na vanjskim zidovima kuće ...." Termin „fasada“ se izjednačava sa terminom „pročelje“ te se poistovjećuje s jednim slojem koji nije direktno povezan s jednim određenim načinom izvođenja završnih radova, no implicira jedan sloj na sistemu nosivih zidova. Sličnu definiciju nalazimo u [14] gdje je „fasada“ 
poistovjećena s „pročeljem“ koje je definirano kao: „lice zgrade [...], a kod slobodno stojećeg ili razvedenog objekta sve vertikalne plohe su pročelja, pa čak i krovište." Ova definicija daje slobodan izbor materijala i tehnologija za obradu pročelja, no pri definiciji „fasaderskih radova“ („oblaganje fasadnih površina prirodnim i umjetnim kamenom...") implicira određene vrste radova i obloga fasade koji ne bi automatski uključivali ostakljene fasade, ventilirane aluminijske fasade i druge suvremene obrade fasada. Oba izvora definiraju termin "fasada“ kao a) istovjetni s terminom pročelje, odnosno jednom stranom (ili više strana) zgrade, b) impliciraju određene radove koje je lakše povezati s tradicionalnim radovima obrade sistema nosivih zidova, iako ih ne definiraju eksplicitno na taj način. Sistem je u [13] definiran kao: „1. ukupnost načela ili stvari usklađenih da čine cjelinu; sustav“, a izjednačava značenje i sa riječi „sustav“. Iako se ne navodi primjer iz arhitektonske discipline, može se zaključiti da fasadni sistem ili sustav može označavati „ukupnost stvari“ usklađenih radi rješenja fasade, odnosno pročelja.

Ovojnicu [13] definira kako slijedi: „mekana, plosnata i tanka površina koja priliježe izvana uz što ...", „tanka opna koja ovija neki plod ili tjelesni organ“, odnosno veže ovaj pojam isključivo uz biološke fenomene. Može se pretpostaviti da se u prenesenom smislu zadržava smisao prislonjenog sloja kao što su toplinske izolacije na pročeljima zgrade, čime bi se opet implicirao sistem nosivih zidova na koji je nanesen neki mekši sloj, npr. toplinska izolacija. Najkonkretniju definiciju termina ovojnica daje [15] koji definira ovojnicu kao: „Ovojnica zgrade jesu ugrađeni dijelovi zgrade koji odvajaju unutrašnjost zgrade od vanjskog okoliša." Prema ovoj definiciji, ovojnicu čine svi dijelovi zgrade koji odvajaju unutrašnjost zgrade od okoliša, a ova definicija također pokriva i različite vrste nosivih konstrukcija i završnih obloga pa može uključivati nosivi zid sa dodatnim slojevima, kao i skeletnu konstrukciju sa staklenim nenosivim elementima te druga moguća tehnološka rješenja. Vidimo da u tumačenjima ovih pojmova postoje određena preklapanja gdje je fasada=pročelje=ovojnica (u onom dijelu koji nije pod ili krov)=fasadni sistem kao ukupnost stvari koja stoji između unutrašnjeg i vanjskog prostora i čini fasadu ili pročelje, zbog čega imamo kružnu referencu.

Radi ovih djelomičnih preklapanja i djelomičnih razlika u terminima koji se svi odnose na vanjske elemente zgrada, u radu se koristi termin fasada u značenju „završni ne nosivi dio pročelja“, gdje se pročelje smatra vanjskim dijelom zgrade koji vidimo, definirano plohom, a koji nije krov ili pod, neovisno o vrsti nosive konstrukcije (u radu su obrađeni primjeri zgrada s različitim nosivim konstrukcijama). „Fasadni sistem“ se koristi kao ukupnost stvari koje čine fasadu ili pročelje, a nisu nosiva konstrukcija zgrade. Ovojnica se koristi u definiciji koja je dana zakonskom regulativom. 
Analiza razvoja fasada i tehnologija Rijeke i riječkog područja je provedena u nekoliko faza. U prvoj fazi dan je okvir razvoja prema osnovnim periodima moderne i suvremene arhitekture prema poznatim svjetskim primjerima. Pregled svjetskih primjera izvršen je uvidom u literaturu i internetske izvore. U drugoj fazi je je analizirana situacija u riječkom području kroz analitičke opise svakog primjera (37 primjera: 29 primjera iz Rijeke i 8 iz okolice). Napravljeno je 110 fotografija te su korišteni pisani i internetski izvori. Napravljeno je 6 vrsta analitičkih i komparativnih tablica, od kojih su u radu prikazane 3.

Kriteriji odabira primjera bili su: raznovrsnost materijala i tehnologija (pronađeno je 12 različitih materijala i 54 varijantnih tehnologija), pokrivenost različitih vremenskih razdoblja i stilova $s$ težištem na suvremenoj arhitekturi (od međuratne arhitekture do 21.stoljeća: moderna 6 , visoka moderna 11 , suvremena arhitektura 18), namjene (stambena 8 , poslovna 5 , javna 16 , mješovita 7 ), važnost primjera od nacionalne do lokalne važnosti (pokrivenost literaturom, pozicija u naselju, priznatost projektanta...), pozicije u centru (Jadroagent, Kraš, Robna kuća RI, Hotel Bonavia, PBZ, Zagrad, Tower...), djela poznatih arhitekata (Ostrogović, Emili, Kučan, Magaš, Randić, Turato, 3LHD ...), ali i djela manje poznatih i novijih ureda ako su se koristili inovativni materijali i tehnologije (MF Arhitekti, MR2 ...).

U završnoj fazi se kronološkom usporedbom te usporedbom prema materijalima i tehnologijama pokušava utvrditi razvoj i povezanost trendova u svijetu i u riječkom području, promjene u korištenju materijala i tehnologija tijekom vremena te odgovoriti na istraživačka pitanja (koja su danas ključni dio pristupa istraživanja u arhitekturi i urbanizmu [16]): 1. Koji materijali i na koji način se upotrebljavaju u kojem periodu i kontekstu u Rijeci? 2. Mijenja li se važnost fasada tijekom vremena (i način obrade), odnosno uočava li se važnost nekih drugih faktora u oblikovanju i prepoznatljivosti objekta? 3. Prati li u Rijeci razvoj materijala i tehnologija svoj razvoj i primjenu u svijetu, odnosno mogu li se uočiti trendovi u tom smislu i preferiraju li se neki materijali umjesto drugih koji se u tom periodu koriste u svjetskom kontekstu? U ovu svrhu izrađene su analitičkokomparativne tablice: 1) Usporedba perioda, namjene, lokacije i materijala, 2) Analitički pregled fasada u svjetskoj arhitekturi od međuratnog razdoblja do danas, 3) Analitičke tablice fasada na lokalnim primjerima - međuratna arhitektura, 2. polovica 20. stoljeća, 21. stoljeće, 4) Analitičke tablice osnovnih značajki zgrada, za navedena razdoblja 5) Sintetičke tablice upotrebe materijala i tehnologija u svjetskoj i lokalnoj arhitekturi, na temelju analiziranih primjera, za navedena razdoblja 6) Komparativne tablice usporedbe trendova u korištenju materijala i tehnologija za fasade, prema svjetskim i lokalnim primjerima, za navedena razdoblja. Na temelju 
ovih analiza i usporedbi napravljena je diskusija rezultata i na kraju dani zaključci.

\section{Fasade u modernoj i suvremenoj arhitekturi}

Tijekom povijesti, zgrade su karakterizirale različite vrste fasada $[1,17$, 18, 19]: različite (često vrlo kvalitetne vrste [20]) žbuke [21], kamen [22], opeka, drvo, keramika... U 19. stoljeću razvoj novih konstrukcija (armiranobetonske, željezne i čelične) omogućuje razvoj fasada nove koncepcije - nenosivih ovojnica (npr. staklene površine, tanke panelske fasade aluminijske legure ili plastične mase), a razvoj materijala i disciplina energetske učinkovitosti dovodi do razvoja toplinskih izolacija te drugačijeg pristupa izvođenja fasada i na sistemima nosivih zidova. Iako se staklene fasade pojavljuju još krajem 19. st. (LeBaron Jenney, Leiter Building Chicago, 1879.) [3], fasade svjetske arhitekture tijekom 20-ih i 30-ih godina još većinom karakteriziraju žbukane fasade (npr. zgrade u WeissenhofSiediung, Stuttgart, 1927.), ili kamene obloge (Paviljon Barcelona, van der Roha, Barcelona, 1929., Palazzo della Civiltà Italiana, Guerrini i dr., Rim, 1937., Bear Runs, Fallingwater, Wright, u Pennsylvaniji, 1939.).

Poslijeratna estetika se izražava npr. kroz upotrebu tehnologije béton brut (Le Corbusier, Unité d'habitation, Marseilles, 1952.). Uz novu upotrebu materijala, fasadu karakteriziraju i duboka profilacija mase pročelja (raster loggia dvostruke visine te armiranobetonski brise-soleili) i jarki kromatizam. U arhitekturi se zadržava (ili ponovo uvodi) obrada ploha keramikom ili bojanim staklom te upotreba kamena. Razvijaju se ovješene fasade, odnosno ostakljene fasade koje su ovješene na nosivu konstrukciju: "curtain-wall" (Belluschi, Equitable Savings and Loan Association, Portland, 1945.-48., van der Rohe, Zgrada Seagram New York, 1958.). Određena eksperimentiranja uključuju i panele od plastičnih masa, nekad ujedno konstrukcija i ovojnica (A. i P. Smithson, House of the Future, 1956.). Razvoj visokih zgrada, nosivih konstrukcija i stakla rezultira pravcem arhitekture visoke tehnologije (HI-Tech - npr. Norman Foster, Zgrada HSBC Hong Kong, 1985.) gdje se na fasadi pojavljuju zahtjevne čelične konstrukcije i staklo. Tijekom postmodernizma, ponovo se javljaju tradicionalni materijali kao što su žbuka (R. Venturi, kuća Vanna Venturi, Chestnut Hill, 1964.) ili kamen (M. Graves, Zgrada Portland, Portland, 1982.).

Suvremenom arhitekturom često se iskazuju tehnološke mogućnosti pa se tako pojavljuju zaobljena stakla, staklene fasade s minimalnim dijelom čeličnih elemenata i slično (Hadid, Stambena zgrada, New York, u izgradnji, Foster + Partners, Apple Park, Cupertino, 2017.). Ne zaboravljaju se ni sada već tradicionalni materijali (kamen, beton, ali i metalne legure ili PVC) već se istražuju mogućnosti njihove upotrebe na nove načine (npr. beton - 
Hadid, Maxxi, Rim, 2010. poliesterske obloge - Hadid, Kulturni centar Heydar Aliyev, Baku, Azerbajdžan, 2012., kamen - RPBW, Valletta City Gate, Malta, 2015.).

\section{Fasade u arhitekturi Rijeke i riječkog područja}

Od sredine 19. stoljeća, Rijeka doživljava gospodarski, urbani i arhitektonski procvat, posebno do 1 . svjetskog rata. U međuratnom razdoblju širi se moderni stil tijekom kojeg nastaju brojne zgrade, a u materijalima je vidljiv utjecaj talijanske škole (kamen, keramička obloga...). Sušački neboder, u tada podijeljenom gradu, radi Josip Pičman (u periodu 1934.-1939.) koji predlaže izvedbu staklenog tornja, a zatim rad nastavlja Alfred Albini (do 1947.). U drugom dijelu grada gradi se poslovna zgrada, R.O.M.S.A. (INA), 1938. arhitekta Enee Peruginija, koja je izuzetan primjer arhitekture racionalizma na ovim prostorima. Brojna je višestambena gradnja, a tipično rješenje je npr. zgrada u Osječkoj ulici, arhitekta Giulija Duimicha, gdje se balkoni linijski ističu svojim zatvorenim punim ogradama, a prozori su, gdje je to bilo moguće, riješeni kao trakasti. Mali neboder, Raoula Puhalija, prepoznatljiv je po zaobljenim linijama kojim zatvara kut bloka i linijskim balkonima. Zgrada Riječkog nebodera - Palača Arbori, arhitekta Umberta Nordia, 1939., tada stambeno poslovne namjene, karakteristična je po svojim jednostavnim linijama pročelja, izraženom konstrukcijskom rasteru i ostakljenjima, ali i oblozi od keramičkih pločica.

Nakon 2. svjetskog rata Rijeka doživljava ekspanziju gradnje, što zbog doseljavanja stanovnika u industrijski centar, što zbog obnove ratom razrušenih dijelova grada. Kako su i dijelovi samog povijesnog centra bili srušeni, tako se neke od zgrada, posebno javne i poslovne namjene, koje se tada grade, nalaze u samom centru grada. Osim obnove centra, prioritet je bila stambena izgradnja koja je $\mathrm{u}$ prvom trenu monokromna (naselja Labinska, Deksa, Zamet, Vulkan), a u drugoj fazi postaje kromatski obrađena (Voplin, Baredice, Ogranak, Turnić, Autoput) [23, 24]. Riječka banka (danas Erste banka) Kazimira Ostrogovića (1965.) preuzima osnovne linije susjednih zgrada, definira kut bloka i komunicira sa svojim okolišem. Bogatu prostornu i volumensku definiciju ujednačuju obloga u kamenu i velika ostakljenja. Jaku stambenu izgradnju do 1980-ih u Rijeci karakteriziraju stambeni tornjevi. Među najuspješnijim primjerima je neboder na Podmurvicama Igora Emilija (1970.) gdje se pojavljuju prefabricirani armiranobetonski elementi koji formiraju filter između vanjskih i unutrašnjih prostora i daju dubinu obradi fasada. Emili 1970-ih u centru grada radi poslovne zgrade Jadroagenta, Kraša, PBZ banke te Robnu kuću Varteks [25], koje interpolira u postojeću izgradnju. U ovim zgradama karakteristično je uklapanje u kontekst razlamanjem volumena ili 
preuzimanjem oblika tradicionalne gradnje, kula ili svodova. Fasade su pak ostakljene u toniranom staklu, obložene kamenim pločama te sa skulpturalnim elementima kao što su mesingane obloge ili izbočeni izlozi. Nešto je drugačija Zgrada Kraša koja definira kut jednog od najvažnijih blokova u centru grada; ima naglašeni konstrukcijski raster, a polja su zatvorena staklom i elementima zasjenjivanja. Turistički kompleks Haludovo, Malinska (1971.), Borisa Magaša u okolici Rijeke se i danas smatra jednim od najznačajnijih primjera turističke arhitekture u Hrvatskoj. Zgradu hotela definiraju prefabricirani paneli „U“ presjeka, velike staklene površine i tanki dematerijalizirani stupovi. Pročelje Robne kuće Ri Ninoslava Kučana (1974.) karakteristično je po industrijskom izgledu megakonstrukcija koji je postignut fasadom iz armiranobetonskih panela i oblogom iz prostorne rešetke. Telegrafsko-telefonski centar (Kučan, 1976) karakterističan je po pročeljima koja su izvedena od bijelih geometrijski obrađenih panela. Naselje Krnjevo (Kučan, 1980.) karakteristično je po organizaciji $s$ vanjskim galerijama i oblogama u crvenom i plavom profiliranom limu [26]. Crkva Sv. Nikole na Turniću (Boris Magaš, 1988.) karakteristična je po svom oblikovanju, gdje su fasada i krov spojeni u isti volumen upotrebom iste kamene obloge.

Od 1990-ih mijenja se ustroj jedinica lokalne samouprave pa je tako područje Općine Rijeka podijeljeno na Grad Rijeku i niz manjih gradova i općina. Područje Grada Rijeke je tada već većinom izgrađeno pa se idućih godina rade obnove već postojećih zgrada, kompleks Kampusa na Trsatu (na području bivše vojne zone), a većina novogradnje se odvija u okolici Rijeke. Jedan od važnijih zahvata je obnova (2000. g., Studio Remik) Hotela Bonavia iz 1886. g. Na fasadi se izmjenjuju svijetli i tamni kamen te strukturalna fasada s tamnim staklom. Isti ured radi kompleks Tower centra koji sadrži trgovački centar, garažni prostor i poslovno-stambeni toranj (2005.-2008.). Pročelja su karakteristična po prefabriciranim armiranobetonskim panelima sa završnim slojem u kuliru te reflektirajućoj staklenoj fasadi. Poslovno-stambeni kompleks Centar Zagrad (ured RandićTurato, 2007.) jedan je od najvećih zahvata u Gradu Rijeci. Na zgradi se pojavljuje više vrsta fasada: kontaktna, ostakljena polustrukturalna, strukturalna, aluminijska, keramički mozaik... Isti ured 2009. godine radi stambeno-poslovnu zgradu u Agatićevoj ulici u centru grada. Fasada i krov imaju jednaku završnu oblogu te se spajaju u istu razlomljenu plohu. Obloga je aluminijska i ostakljena reflektirajućim staklom. Sportski Centar Zamet (ured 3LHD studio, 2009. g.) sadrži dvoranu, poslovne, rekreacijske, prodajne i uslužne prostore, garažu i vanjski trg, a karakteriziraju ga oblikovanje i keramičke obloge. Sveučilišni Kampus na Trsatu je zona s više fakulteta i pomoćnih sadržaja Sveučilišta, a zgrade su otvorene između 2012. i 2016. godine. Islamski centar Rijeka (idejno rješenje kipar Dušan 
Džamonja, projekt ADB d.o.o Zagreb, 2013.) sadrži izuzetno zahtjevne ljuskaste konstrukcije $\mathrm{u}$ armiranom betonu te ga krase različite vrste fasada. Zgradu JGL (Rožić arhitekti i Katušić Kocbek arhitekti, 2015.) karakterizira zaobljeni volumen obložen profiliranim limom. Poslovno-stambene zgrade uz Kampus (ureda MR2) na pročeljima alterniraju kontaktnu i ventiliranu ostakljenu fasadu (novost u riječkom području), a dodani su i volumeni radi raspršivanja djelovanja vjetra. Višestambena zgrada (Studio Area arhitektura) ima klasičnu kontaktnu fasadu. DV Katarina Frankopan, Baška (MF Arhitekti, 2011.) karakteriziraju prefabricirani armiranobetonski paneli s kamenom. Ured Idisa Turata 2014. na sličan način definira pročelje dvorane u Krku, gdje je na armiranobetonskim panelima prenesen motiv gromača. Izvadak iz analitičke tablice prema analiziranim razdobljima je dan u Tablici 1, a zbog prostornog ograničenja prikazani su samo radovi iz najnovijeg razdoblja koje odlikuje iznimna raznolikost materijala i tehnologija ili inovativni proizvodi.

Tablica 1. Analitička tablica prema analiziranim razdobljima - izvadak

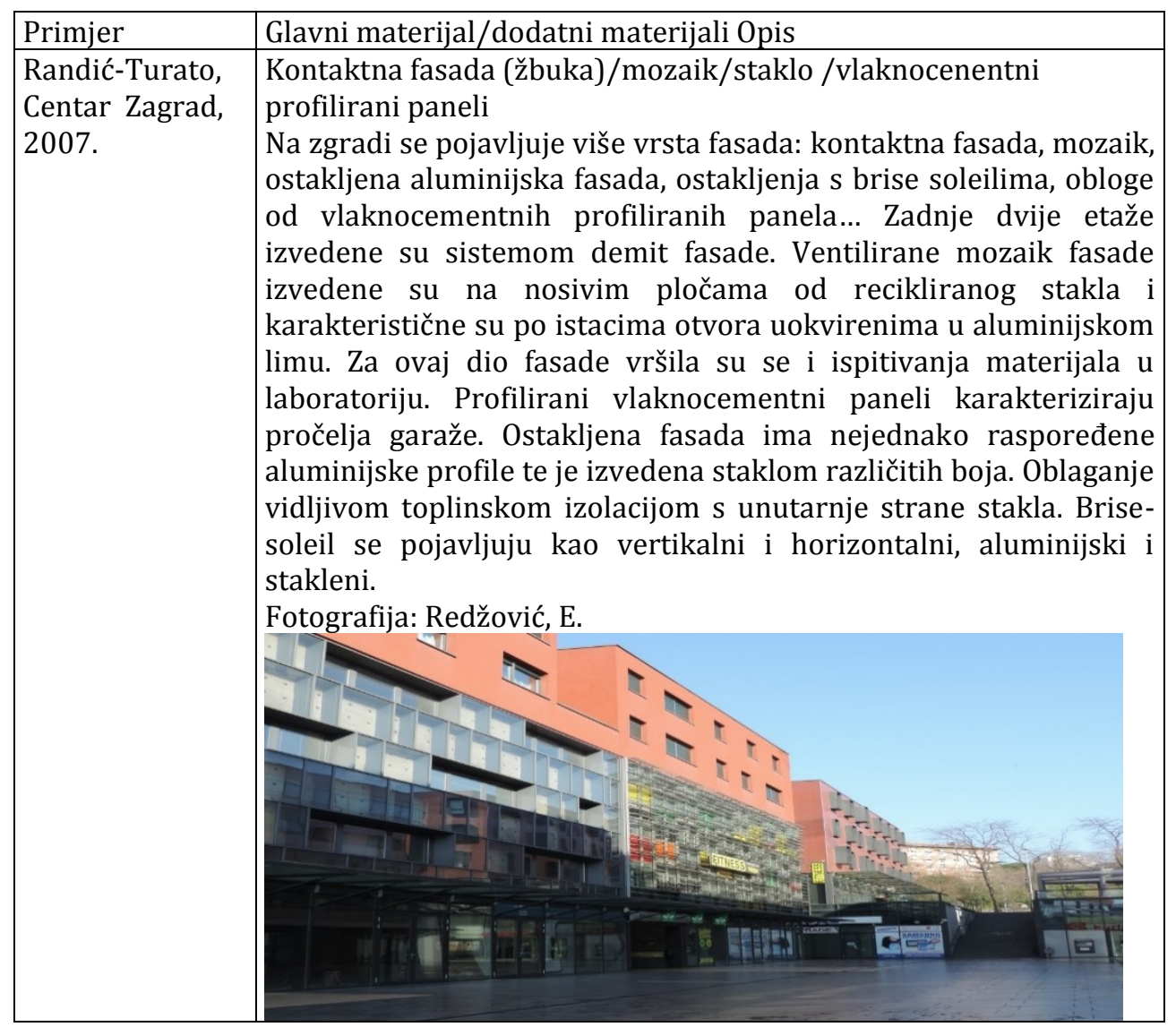




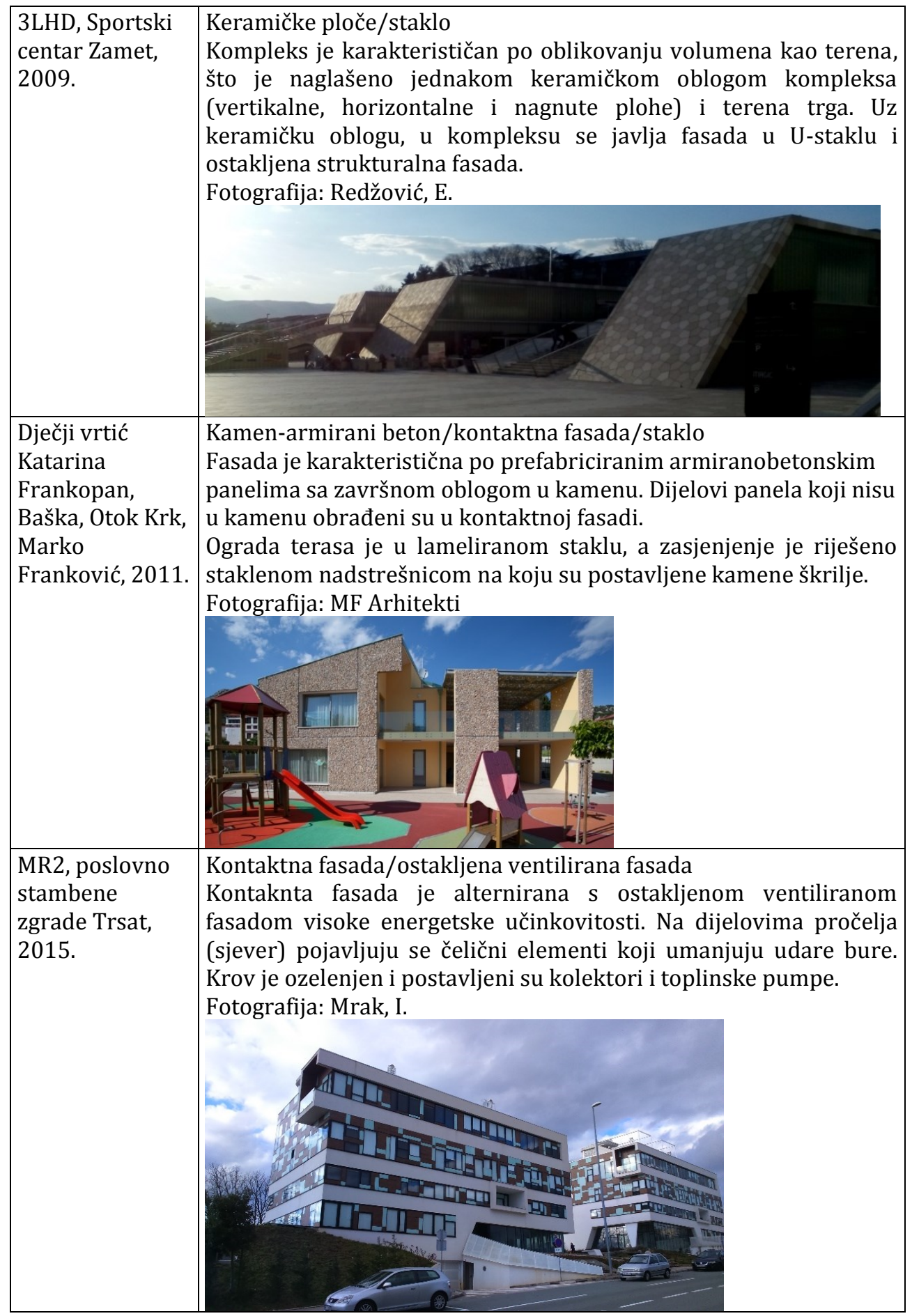




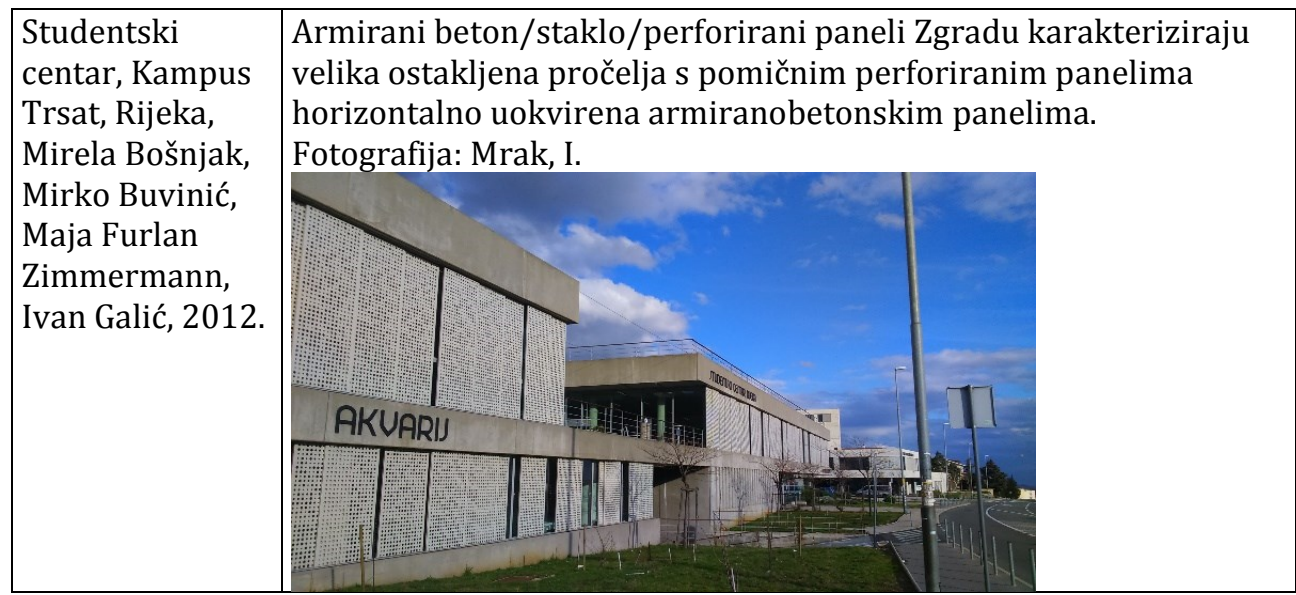

\section{Rasprava}

Detaljnim uvidom na terenu i u dokumentaciju te analitičkokomparativnom analizom nastoji se odgovoriti na istraživačko pitanje br.1. U međuratnom razdoblju su prvenstveno zastupljeni žbuka i kamen, a sistem je kontaktna fasada (završni sloj se nanosi direktno na nosivi zid). Značajni dio ploha je ostakljen te je staklo najčešći materijal koji dolazi u kombinaciji s drugim osnovnim materijalom. U svim analiziranim primjerima (8) jedan materijal je prevladavajući, a sekundarni je staklo, sistem je kontaktni. Kao treći materijal, u 2 primjera pojavljuje se kamen. U drugom dijelu 20. stoljeća pojavljuju se staklo, žbuka, kamen, armirani beton, a rijetko drugi materijali kao aluminij, čelični lim, čelična rešetka, mesing... Staklo se prvenstveno pojavljuje kao ostakljenje otvora, a rjeđe kao ovješena fasada (Jadroagent, PBZ, Riječka banka...).

Pojavljuju se primjeri trodimenzionalno oblikovanih površina (Robna kuća Ri, PBZ, Telegrafski centar), ali predstavljaju rijetkost. Rijetko se pojavljuju elementi zasjenjena kao jedan od glavnih motiva na fasadama (Kraš...). Sistemi izvođenja fasada su većinom kontaktni, a dijelom se javljaju i ovješene staklene fasade (npr. kontinuirana fasada - Jadroagent). U većini analiziranih primjera (6/11) prevladavaju 2 materijala (npr. žbuka i armirani beton, staklo i armirani beton, staklo i kamen, aluminij i armirani beton), 2 primjera karakteristična su po 3 materijala, a u 1 primjeru dominira 1 materijal (aluminij).

Velika razlika vidi se $\mathrm{u}$ broju različitih korištenih sekundarnih materijala: 5 materijala se pojavljuje u 1 primjeru (PBZ), 4 materijala u 2 primjera, dok se u ostalim primjerima pojavljuje manji broj materijala. Najčešći sistem je kontaktni, a pojavljuju se i ovješene fasade (kontinuirane ostakljene fasade). U primjerima iz 21. stoljeća pojavljuju se staklo, 
kontaktna fasada na toplinskoj izolaciji (današnja obrada koja daje dojam žbuke), kamen, armirani beton, a rjeđe keramika, lim, HPL, vlaknocementni paneli, istezi i drugi materijali. Staklo se i dalje više pojavljuje kao ostakljenje otvora (15 puta), ali je sve češća i ovješena fasada ( 9 puta). Trodimenzionalna obrada površina se pojavljuje 4 puta (prvenstveno se radi o različitim tehnologijama armiranog betona ili vlaknocementnih panela), ali je i dalje rijetkost. Elementi zasjenjivanja se pojavljuju 4 puta, odnosno i dalje su rijetkost. Zastupljeni sistemi se najčešće pojavljuju u kombinacijama (kontaktna, ventilirana i ovješena; ovješena i ovješena iz različitih materijala; ventilirana i ovješena...), a rjeđe se koristi 1 sistem (ventilirana fasada ili kontakt). U većini primjera pojavljuju se 2-3 materijala (15 primjera, obično staklo i drugi materijal), u 6 primjera podjednako su zastupljena 3 materijala, u 2 primjera pojavljuju se 4 materijala, u 1 primjeru čak 8 materijala i 10 različitih tehnologija (Zagrad), a u 1 primjeru 4 materijala (no pojavljuje se 5 varijantnih tehnologija - IC Rijeka). Primjećuje se velika zastupljenost tipskih tehnoloških rješenja kao što su aluminijski bond paneli, demit fasade, kontinuirane, strukturalne i polustrukturalne fasade, rjeđe adaptacija prefabriciranih elemenata postojećem projektu (kulir paneli - Tower centar, kontinuirana fasada s vidljivom kamenom vunom - Zagrad, armiranobetonski paneli - kompleks Studentskog standarda i SC) ili inovativni sistemi (paneli u armiranom betonu Sportske dvorane na Krku, DV K. Frankopan, ventilirana ostakljena fasada - zgrade na Trsatu, keramička obloga - Zagrad...).

Vremenom se povećava broj upotrebljavanih materijala, posebno se povećava broj korištenih materijala unutar jedne fasade, a učestalije su i kombinacije različitih sistema. Dok u međuratnom razdoblju zapažamo 5 materijala i tehnologija, u 2. polovici 20. stoljeća zapažamo 9 materijala i 15 tehnologija, a u 21. stoljeću 12 materijala i 34 varijante tehnologija (npr. strukturalna i kontinuirana fasada kao 2 varijante ovješene ostakljene fasade).

Usporedbom osnovnih značajki koje karakteriziraju analizirane zgrade (tablica nije prikazana zbog prostornog ograničenja) pokušava se utvrditi odgovor na istraživačko pitanje br. 2. Primjećuje se da je u međuratnom razdoblju definicija volumena u 4 primjera osnovna prepoznatljiva karakteristika, a fasada u 2 primjera. U 2. polovici 20.stoljeća fasada je u 10 primjera osnovna značajka, a u 1 primjer je to volumen (crkva Sv. Nikole...), a u 1 primjeru nalazimo kao značajku i konstrukciju (svod - Jadroagent). U 21.stoljeću fasada je u 16 primjera osnovna značajka, a volumen u 3 (Agatićeva, Sporstki centar Zamet, kuća u Njivicama...), pa možemo zaključiti da je fasada sve češće osnovna značajka zgrade, što je u skladu s tradicijom 2. polovice 20. stoljeća. Velika razlika se tijekom vremena uočava u tehnologijama fasada, gdje se prvenstveno povećava udio tipskih 
proizvodnih sistema (ovješena fasada s aluminijskim panelima, HPL, vlakno cementni, armiranobetonski paneli, kontinuirana i strukturalna ostakljena fasada, istezi i perforirani paneli, demit fasada...), ali i tehnologija koje se razvijaju kao odgovor na sve veći značaj fizike zgrade: kontaktna fasada $s$ toplinskom izolacijom, ventilirana fasada. U međuratnom razdoblju imamo kontaktne fasade, $\mathrm{u} 2$. polovici 20 . stoljeća 1 ovješenu ostakljenu fasadu i 10 kontaktnih, a u 21. stoljeću među analiziranim primjerima uočavamo 10 kontaktnih fasada s toplinskom izolacijom, 13 ventiliranih fasada, 16 ovješenih metalnih ili ostakljenih fasada, od kojih 1 ostakljena ventilirana. Samo na pojedinim primjerima pokušalo se odgovoriti i na karakteristične lokalne uvjete - kišu (Zagrad, Građevinski fakultet), osunčanje (Zagrad, Građevinski fakultet, zgrade Studentskog standarda) i buru (stambenoposlovne zgrade na Trsatu).

Sintetizirajući podatke o materijalima i tehnologijama u svijetu i riječkom području, te usporedbom zapažanja o podacima (izvadak iz sintetičke tablice je dan u Tablici 2, a komparativna zapažanja u Tablici 3 u obje tablice zbog prostornog ograničenja prikazani su samo period 2 . polovice 20. st. ili 21. st.) nastoji se dati odgovor na istraživačko pitanje br. 3.

U međuratnom razdoblju (analizirano je 20 primjera) u svjetskim primjerima dominantna je upotreba žbuke te kamena u primjerima skuplje izvedbe, a važnost dobivaju velike ostakljene stijene te trakasti prozori. U Rijeci je u ovom razdoblju također dominantna upotreba žbuke te kamena u primjerima skuplje izvedbe, pojavljuju se i velike ostakljene stijene te trakasti prozori. U drugoj polovici 20. st. u svjetskim primjerima možemo zamijetiti nekoliko faza razvoja fasada. U poslijeratnom razdoblju koristi se vidljivi armirani beton ili žbuka, a važni su detalji: kolorističke obrade, reljefi, mozaici i slično. U skupljoj varijanti, posebno u SAD, razvijaju se ostakljene fasade, npr. sistem curtain-wall. Cijelo 20. st. koriste se i tradicionalni materijali kao što su fasadna opeka i kamen. Krajem 20. st. koriste se različiti materijali, a posebno se razvijaju metalne obloge. $\mathrm{Na}$ primjerima fasada iz svjetske arhitekture možemo pratiti dva različita stava - kombinirano korištenje više različitih materijala te pozornost prema teksturi i dubini fasade, ili jednoličnu monokromnu izvedbu volumena u pretežito jednom materijalu, nekad u skulpturalnom, a nekad $u$ jednostavnom obliku. U poslijeratnom razdoblju u Rijeci izvedba fasada je većinom iz žbuke, ali sa posvećivanjem pažnje obogaćivanju fasada kromatskom obradom. Od 1960-ih u skupljim varijantama koriste se kamen i ostakljenja značajnih dijelova fasada, ali eksperimentira se i sa drugim oblogama: armiranim betonom, limom, prostornim rešetkama... Obrada fasada i definicija volumena su povezani te tvore cjelinu, što je posebno vidljivo kod razlomljenih volumena u centru grada ili kod objekta za kult. 
Oba trenda su donekle u skladu sa svjetskim trendovima, ali su uočavaju dvije karakteristike: manja upotreba sistema curtain-wall i veća zastupljenost kombinacije različitih materijala i tehnologija u svim vrstama zgrada. U 21. stoljeću u svjetskim primjerima vidimo korištenje svih tradicionalnih te novih materijala, a posebno razvoj upotrebe stakla. Materijali se većinom koriste u kombinaciji, a nekad jedan materijal u potpunosti prevladava - većinom se tada radi o plemenitijim ili novijim materijalima: kamen, drvo, staklo, polikarbonat... Skulpturalni oblici volumena su sve češći, a fasade su često istaknute trodimenzionalne teksture ili dubine postignute dubokim perforiranim slojevima $i$ mehaničkim sistemima.

Tablica 2. Usporedba materijala i tehnologija - izvadak

\begin{tabular}{|c|c|}
\hline $\begin{array}{l}\text { 21.st. } \\
\text { Opći } \\
\text { trendovi }\end{array}$ & $\begin{array}{l}\text { Vidljivi beton - beton sa završnom glatkom površinom, koriste se } \\
\text { suvremeni betoni poput SCC betona } \\
\text { Kamen - ravna linijska ploha, skulpturalno rezani } \\
\text { Kamen - različite vrste kamena, kombinacije } \\
\text { Staklo - staklene stijene } \\
\text { Staklo - ovješene fasade (curtain-wall), s različitim stupnjevima } \\
\text { istaknutosti nosivih profila } \\
\text { Metalne legure - različiti materijali, profilirani limovi, perforirani } \\
\text { lim, npr. prema slici... } \\
\text { HPL ploče, vlaknocementne ploče - živih boja, različitih oblika } \\
\text { Plastične mase - glatke površine, zakrivljene površine } \\
\text { Boje - kromatizam, različite boje, prvenstveno kao dio materijala }\end{array}$ \\
\hline $\begin{array}{l}\text { 21.st. } \\
\text { Rijeka i } \\
\text { okolica }\end{array}$ & $\begin{array}{l}\text { Ožbukana fasada - na toplinskoj izolaciji se izvode završni premazi } \\
\text { Vidljivi beton - beton sa završnom glatkom površinom } \\
\text { Vlaknocementni paneli } \\
\text { Armiranobetonski paneli - završni sloj beton ili drugi } \\
\text { Kamen - ravna linijska ploha, nepravilne plohe } \\
\text { Kamen - različite vrste kamena, kombinacije } \\
\text { Staklo - staklene stijene } \\
\text { Staklo - ovješene fasade (curtain-wall), s različitim stupnjevima } \\
\text { istaknutosti nosivih profila, ventilirane fasade } \\
\text { Staklo - trakasti prozori } \\
\text { Metalne legure - dio pročelja, eksperimentiranje s različitim } \\
\text { legurama: aluminij, profilirani limovi... } \\
\text { Reljef - kao dio prefabriciranja ab ili vlaknocementnih panela } \\
\text { Mozaik - koristi se rijetko, na vanjskim I unutrašnjim površinama } \\
\text { Boje - kromatizam, različite boje, kao karakteristika materijala ili } \\
\text { kao dodatno aplicirani sloj } \\
\text { Brise-soleil - kao dio fasada, metalni }\end{array}$ \\
\hline
\end{tabular}


Tablica 3. Usporedba trendova u korištenju materijala i tehnologija za fasadeizvadak

\begin{tabular}{|c|c|}
\hline 21.st. & \\
\hline $\begin{array}{l}\text { Opći } \\
\text { trendovi }\end{array}$ & $\begin{array}{l}\text { Može se primijetiti raznovrsnost materijala i tehnologija, kao što } \\
\text { su žbuka, vidljivi beton, metalne obloge, staklene stijene, učestala } \\
\text { upotreba metalnih legura za profile ostakljenja, korištenje novijih } \\
\text { materijala kao što su vlaknocementni paneli, poliesterske ploče, } \\
\text { HPL ploče... } \\
\text { Posebno se ističe korištenje zakrivljenih površina, raznih obrada } \\
\text { kao perforacija, ispisa, skulptoralnih oblikovanja, različita } \\
\text { kromatika... } \\
\text { Fasadna površina je jedan od osnovnih elemenata koji } \\
\text { karakteriziraju oblikovanje zgrade: bojom, ali i teksturom. } \\
\text { Karakteristična je upotreba svih vrsta materijala u kombinaciji u } \\
\text { jednoj zgradi. }\end{array}$ \\
\hline $\begin{array}{l}\text { Rijeka i } \\
\text { okolica }\end{array}$ & $\begin{array}{l}\text { Može se primijetiti raznovrsnost materijala i tehnologija kao što su } \\
\text { žbuka, vidljivi beton, metalne obloge, staklene stijene, učestala } \\
\text { upotreba metalnih legura za profile ostakljenja te korištenje } \\
\text { kamenih obloga. } \\
\text { Posebno se razvijaju armiranobetonski paneli sa završnim slojem: } \\
\text { kamen, kamena zrnca, reljef prema upotrebi matrica... (također i } \\
\text { prefabricirani vlaknocementni paneli). } \\
\text { Upotrebljavaju se prefabricirani paneli i istezi. } \\
\text { Curtain-wall se rijetko primjenjuje. } \\
\text { Fasadna površina je jedan od osnovnih elemenata koji } \\
\text { karakteriziraju oblikovanje zgrade: ostakljene fasade, višeslojne } \\
\text { ostakljene fasade, ventilirane fasade, brise-soleli... } \\
\text { Puno se upotrebljavaju metalni elementi te se razvija upotreba } \\
\text { ostakljenih fasada. } \\
\text { Fasade su još uvijek većinom plošne, ali se mogu vidjeti i primjeri } \\
\text { prostorno oblikovanih fasada, najčešće upotrebom nadstrešnica i } \\
\text { brise-soleila. } \\
\text { U poslovnim zgradama česta je upotreba metalnih obloga, rjeđe } \\
\text { armirano betonskih. } \\
\text { Stambena izgradnja je skromnije opremljena pa se koristi žbuka } \\
\text { (kontaktna fasada s toplinskom izolacijom), a dojam se obogaćuje } \\
\text { detaljima u staklu i metalu. Razvija se svijest o utjecaju klime pa se } \\
\text { pojavljuje i ventilirana ostakljena fasada i elementi za raspršivanje } \\
\text { vjetra. } \\
\text { Osnovna kombinacija materijala je metalna obloga i ostakljenje. } \\
\text { Zgrade su većinom definirane kao jednostavni volumeni. }\end{array}$ \\
\hline
\end{tabular}

U Rijeci i okolici u 21.st. posebno je istaknuta upotreba metalnih panela za oblogu svih vrsta zgrada, od stambenih, poslovnih, do proizvodnih namjena. Ostakljenja su važan dio fasada, no samo na jednom primjeru je cijela zgrada izvedena s ovješenom fasadom. Koriste se različite vrste 
materijala, no $\mathrm{u}$ principu se koristi jedan materijal (odnosno dva: $\mathrm{u}$ kombinaciji sa staklom) na jednostavnim kutijastim volumenima, bez ili sa malo detalja. Značaji odmak predstavljaju kompleks Zagrad u kojem se pojavljuje kombinacija fasada te se radi i na dubini fasade te zgrada $u$ Agatićevoj, gdje su krov i fasada unificirani u jedinstveni volumen (no i ovdje se radi o jednom materijalu u kombinaciji sa staklom). Kombiniranje materijala i tehnologija je karakteristično i za Islamski centar, gdje je posebno značajna obloga kupola u kojoj je svaki dio posebno rađen u skladu sa svjetskim suvremenim trendovima i tehnologijama. Eksperimentiranje tehnologijama je više iskazano u zgradama koje su nastale u okolici Rijeke, kao u vrtiću u Baški (MF Arhitekti) i dvorani u Krku (Turato), gdje su spojeni aspekti tradicionalne gradnje s lokalnom proizvodnjom armiranog betona te u ventiliranoj ostakljenoj fasadi u zgradi na Trsatu (Ured MR2).

\section{Zaključak}

Razvoj tehnologija kroz suvremeno doba, od 2. polovice 20. stoljeća i u 21. stoljeću je i dalje rijetka tema istraživanja (posebno 21. stoljeće), a posebno s aspekta evolucije završnih radova, iako su upravo ovi radovi doživjeli izniman razvoj, možda usporediv s razvojem konstrukcija u 19. i na početku 20. stoljeća. Rad doprinosi boljem razumijevanju uloge fasadnih materijala i tehnologija u definiciji fasada na riječkom području od međuratnog razdoblja do danas, $\mathrm{s}$ posebnim težištem na suvremenu arhitekturu. Posebno se to odnosi na razumijevanje vremenskog razvoja fasada i promjene pristupa fasadama, utjecaj važnosti fasada i mogućih drugih karakteristika u definiciji zgrada te utjecaj različitih faktora na definiciju suvremenih fasada. Tijekom istraživanja utvrđeni su i neočekivani rezultati, npr. izvor inovativnosti u tradicionalnim lokalnim industrijama i građevinskim materijalima te suvremenom inženjerskom modeliranju. Uspoređujući materijale i tehnologije na primjerima riječkog područja kroz vrijeme uočavamo sve veći izbor materijala, a posebno varijantnih tehnologija. U 21. stoljeću vodi se računa o energetskoj učinkovitosti fasada, a izraženo je i korištenje predgotovljenih fasadnih elemenata.

Uspoređujući materijale i tehnologije na svjetskim i primjerima riječkog područja primjećujemo da razvoj i korištenje fasada u Rijeci i okolici slijedi njihovo korištenje u ostatku svijeta, iako u različitim periodima, od moderne do danas, ne nalazimo najskuplje varijante fasada. U periodu moderne $\mathrm{u}$ Rijeci i okolici se koriste osnovni materijali kao i u svijetu, ali na nešto skromniji način. U periodu nakon 2. svjetskog rata, pretežna je skromnija izgradnja čije fasade karakterizira žbuka. Od 1960-ih grade se bogatije opremljene zgrade pa se na fasadama poslovnih zgrada nalazi kamen (i to u pločama ravnih linija i glatkih ploha). Iako se radi o pojedinačnim 
primjerima, fasade u Rijeci i okolici slijede trendove u estetici i tehnologiji. Javljaju se curtain-wall fasade, ali $u$ manjem obimu nego $u$ drugim državama, posebno u odnosu na SAD, a sama tehnologija je obično namijenjen samo za dijelove fasade. Jako je pak izraženo kombiniranje materijala i sistema. Skromnija izvedba je posebno vidljiva u suvremenoj arhitekturi, gdje su neki svjetski primjeri izuzetno tehnološki i financijski zahtjevni. U 21. stoljeću u Rijeci se kao i u svijetu koriste različiti materijali, ali s nekim razlikama: u riječkom kontekstu dominiraju metalne obloge te ponešto armiranobetonski i vlaknocementni paneli posebne obrade (također rijetki). Iako se sve više povećavaju površine ostakljenja, rijetke su potpuno ostakljene fasade ili fasade iz lameliranog stakla (nema ih). Nema izuzetno novih materijala (s nanotehnologijama, tekućim kristalima i slično) ili tehnologija (automatizirane fotosenzibilne fasade, led fasade i slično). Fasade većinom definiraju zgradu bojom. Manje je kombinacija materijala, a kompleks Zagrad je rijetki primjer bogato izvedene fasade (kombinacija materijala, dubina, boja, teksture...). Čest je princip apliciranja tipskih fasadnih sistema, što rezultira plošnim jednostavnim plohama fasada i jednostavnim volumenima. Značajno je nastavljanje tradicije kombinacije materijala i tehnologija na fasadama jednog objekta, a također se inovativniji pristupi javljaju na temelju tradicije domaće proizvodnje (reljefni armiranobetonski paneli i ventilirana ostakljena fasada su proizvedeni prema narudžbi kod lokalnih proizvođača), dok upotreba standardiziranih elemenata (npr. bond paneli..) često proizvodi neinventivna rješenja koja djeluju jednako neovisno o lokaciji i namjeni, a tada se uniformiranost uspijeva umanjiti samo iznimno bogatom paletom materijala i tehnologija.

Obrada fasade tijekom vremena nema uvijek istu važnost i nije uvijek glavni element definiranja oblikovanja zgrade. U moderni je stil zgrade prvenstveno definiran volumenom, a materijali su jednostavni i plošni. Nakon 2. svj. rata u svijetu fasade ponovo dobivaju trodimenzionalnost teksture, i različite boje, a slična pozornost se obraća definiciji volumena, kao i definiciji ploha. Možda je najveća razlika u svjetskim trendovima i u Rijeci vidljiva u 21. stoljeću, kada fasade u Rijeci ponovo gube trodimenzionalnost teksture.

U najbližoj fazi suvremene arhitekture u riječkom području možemo ustanoviti neke zanimljive fenomene kao što je znatno odstupanje u oblikovanju i fasadama obzirom na svjetske trendove, jer se u Rijeci preferiraju fasadne obrade ravnim panelima na jednostavnim volumenima, što je u srazu sa sve češćim skulpturalnim oblicima i dubokim fasadama te fasadama koje kombiniraju različite vrste materijala (učestale u svjetskim primjerima). Kao izuzetak pojavljuje se nekoliko primjera: SC Zamet, Centar Zagrad, a u okolici Rijeke vrtić u Baški i dvorana u Krku. U okolici Rijeke je 
češće vidljivo korištenje fasada inspirirano tradicionalnim materijalima, prvenstveno kamenom, koji se pokušava upotrijebiti na novi način ili kao grafička inspiracija (prijenos vizualnih informacija, no bez prijenosa materijala). Pažnja prema fizici zgrade u lokalnim primjerima nije rezultirala inovativnim rješenjima već prvenstveno apliciranjem tipskih rješenja (kontaktna „demit“ fasada, ventilirana fasada s aluminijskim panelima). Samo u jednom primjeru, gdje je rađeno modeliranje ponašanja zgrade pri zagrijavanju i buri, rezultat je inovativno rješenje (zgrade na Trsatu ureda MR2), koje je također umanjeno ekonomičnom izvedbom.

Najinovativnija rješenja se pokazuju ona koja spajaju lokalnu proizvodnju s projektnim idejama, što rezultira novim načinima korištenja tradicionalnih materijala, zanimljivim vizualnim rješenjima ili inovativnim tehnološkim rješenjima te pristupi bazirani na modeliranju klimatskih pojava.

Ovi zaključci nam pokazuju i moguća daljnja istraživanja te rad može biti baza za istraživanje sljedećih tema: odnos proizvodnje i inovacija u suvremenoj gradnji, mogućnost poticanja suradnje projektanata i lokalnih proizvođača, pristupi definiranja volumena i fasada na temelju suvremenog modeliranja zgrada, važnost ostalih oblikovnih elemenata (volumena i konstrukcije). Rad je također baza za daljnje povijesno istraživanje fasada i fasadnih tehnologija kroz arhivske dokumentacije radova. Posebno se uočava važnost i hitnoća organizacije arhivske građe 2 . polovice 20 . stoljeća koja se velikim dijelom možda i izgubila - krajem prošle države, pretvorbom i gašenjem brojnih poduzeća pa tako i projektantskih ureda - možda u vidu osnivanja instituta. Prikupljanjem ove građe moglo bi se doći do uvida u stvarni tijek projekta i izvođenja u poslijeratnom razdoblju i suvremenom dobu.

\section{Literatura}

[1] Pevsner, N. (2006) An Outline of European Architecture. 1975. London : J. Murray. Original 1945. London: Penguin.

[2] Giedion, S. (1954) Space, Time and Architecture - The Growth of A New Tradition. Cambridge: Harvard University Press, 1954 (Original 1941.)

[3] Gössel, P., Leuthäuser, G. (2007) Arhitektura 20. stoljeća. Zagreb : V.B.Z.

[4] Zakon o gradnji NN 153/13, 20/2017

[5] Ching, F.D.K. (2014) Building Construction Illustrated, 5th Edition. Hoboken, New Jersey: John Wiley \& Sons

[6] Palinić, Nana, (2009). Rane armiranobetonske konstrukcije u riječkoj luci. Građevinar, 2009, 61(5), str. 435-444.

[7] Glavočić, D., ur. (1997). Arhitektura secesije u Rijeci. Rijeka: Moderna galerija. 
[8] Lozzi-Barković, J. (2010) Secesija u arhitekturi Rijeke: arhitektura i urbanizam s početka 20. stoljeća 1900-1925. Rijeka: Izdavački centar Rijeka.

[9] Rotim-Malvić, J., ur. (1996) Moderna arhitektura Rijeke: arhitektura i urbanizam međuratne Rijeke 1918.-1945. Rijeka: Moderna galerija.

[10] Lozzi-Barković, J. ( 2015) Međuratna arhitektura Rijeke i Sušaka: usporedba i europsko okruženje. Rijeka: Adamić.

[11] UNESCO Mexico City Declaration on Cultural Policies. Final report. World Conference on Cultural Policies, Mexico City, 26 July - 6 August 1982, Pariz: UNESCO. http://unesdoc.unesco.org/images/0005/000525/052505eo.pdf (20.04.2018.)

[12] Urevbu, A. O. (1997) Culture and Technology : a Study on the 1997 Theme. Pariz: World Decade Secretariat, Unesco

[13] Anić, V. (2004) Veliki rječnik hrvatskoga jezika. Zagreb: Novi liber.

[14] Simović, V. ur. (2002), Leksikon građevinarstva. Zagreb: Masmedia.

[15] Tehnički propis o racionalnoj uporabi energije i toplinskoj zaštiti u zgradama, Narodne novine 128/15

[16] Groat L. N., Wang, D. (2013) Architectural Research Methods. 2. izdanje. New Jersey: John Wiley \& Sons

[17] Peulić, Đ. (2002) Konstruktivni elementi zgrada. 3. izdanje. Zagreb: Croatia knjiga.

[18] Deplazes, A., ur. (2008) Constructing Architecture: Materials, Processes, Structures: a Handbook. Zurich: Darch Eth.

[19] Torricelli, M.C., Del Nord, R., Felli, P. (2012) Materiali e tecnologie dell'architettura. Milano: Editori Laterza.

[20] Vadstrup, S. (2008) Conservation of Plaster Architecture on Facades - Working Techniques and Repair Methods. Raadvad, Danska: Centre for Building Preservation.

[21] Salavessa, E., Jalali, S., Sousa, L.M.O., Fernandes, L., Duarte, A.M. (2013) Historical plasterwork techniques inspire new formulations. Construction and Building Materials, 2013,48, str. 858-867.

[22] Crnković, B., Šarić, Lj., (2003) Građenje prirodnim kamenom. Zagreb: IGH.

[23] Škunca, S. (2014) Koloristička obrada pročelja višestambene riječke arhitekture druge polovice 20. stoljeća kao polazište obnove kroz projekt podizanja energetske učinkovitosti Sveučilište u Rijeci. U: Arbanas, Ž., ur.

Zbornik radova Građevinskog Fakulteta Sveučilišta u Rijeci. XVII. Rijeka, Građevinski fakultet, str. 177-196

[24] Glavočić, D., Rotim-Malvić, J., Škunca, S. (2017) Riječka radnička naselja. Rijeka: Pro Torpedo.

[25] Schwalba, R., Dobrović, E. (1999) Igor Emili. Rijeka: Muzej Grada Rijeke.

[26] Dubrović, E. (2006) Ninoslav Kučan, katalog izložbe. Rijeka: Muzej grada Rijeke. 